IJLRES - International Journal on Language, Research and Education Studies ISSN: 2580-6777 (p); 2580-6785 (e)

Vol. 1, No. 2, 2017

Page: 226 - 239

\title{
THE EFFECT OF LEARNING STRATEGY AND READING INTEREST TO THE READING UNDERSTANDING ABILITY OF STUDENTS OF IAIN BUKIT TINGGI
}

\author{
Reflinda \\ reflindaali@rocketmail.com
}

State Isntitute for Islamic Studies of Bukit Tinggi, Indonesia

\begin{abstract}
This study aims to determine the influence of learning strategies and reading interest on the ability of reading comprehension of IAIN Bukittinggi students. The question posed is: Whether the discoveri learning strategy associated with learning interests is better than expository learning. The research population is a $5^{\text {th }}$ semester student at the Department of Religious Education at IAIN Bukittinggi. Samples are taken in two classes where one class is taught by a discoveri strategy and the other is taught by an expository strategy. Data were analyzed by using $t$ test (different test). The results show that discover learning strategies in high interest groups and low interest have higher learning outcomes than classes taught with expository strategies.
\end{abstract}

\section{Keywords: Learning Strategy, Discovery, Ekspository, Learning Interest}

\section{INTRODUCTION}

Reading is one of the most important skills of every student. Imagine, because students who are studying in college should be able to explore and develop the knowledge that is being demanded, among others and especially by reading. Every student should always read books, journals or sources that are related to lecture material that is being followed or studied.

In good reading it takes a variety of skills and specific goals. The reader should actively look for reading material and always interact with the reading material, because reading is an active and interactive activity that can only be done by using mind and full attention. Reading activities like this should be done with silent reading, or so-called reading for comprehension.

This reading comprehension skill needs to be applied by students well in order to obtain good results in understanding the ideas or ideas contained in the reading material. A good student of reading comprehension skills will certainly have many 
The Effect of Learning Strategy and Reading Interest to the Reading Understanding Ability of Students of IAIN Bukit Tinggi

accesses to existing knowledge. This is in line with Tarigan's opinion that comprehension reading skills are the key to all knowledge.

From the description above, it is clear that reading is a powerful infrastructure for gaining direct access to the main source of knowledge. There are several factors that influence the ability to read the understanding of intrinsic factors (within) and extrinsic factors (outside the self). Intrinsic factors include mental, physical, attitude, interests, study habits, learning motivation, gender, health, and age. Extrinsic factors include the level of parent education, teaching-learning situation, parent income, curriculum, and environment in general. These factors interact in influencing one's reading comprehension skills.

On the other hand, Tarigan ${ }^{1}$ said that many factors that cause less successful students in understanding the reading, among others caused by (1) language skills, (2) language competence consisting of semantic competence, syntactic competence, discourse competence, and sociolinguistic competence, (3) general knowledge, (4) cognitive skills, (5) physical factors, (6) teaching methods, and (7) subject matter.

Based on these conditions, it is necessary to do engineering learning in the classroom by applying methods, approaches or learning strategies undertaken by lecturers in the lecture to improve students' reading comprehension. The methods, approaches or strategies chosen to be implemented should effectively increase the interest and read the students' understanding.

\section{LITERATURE REVIEW}

\section{Ability of Understanding Reading}

Reading means conducting linguistic interaction activities to reveal the meaning contained in the writings submitted by the author. Smith and Robinson; Hugson ${ }^{2}$ said that reading is not a passive activity, but is an active activity that the reader can to express the meaning contained or information apasaja submitted by the author.

Based on this explanation it can be understood that although reading is basically a receptive activity, it is active in which the reader continually seeks out any

\footnotetext{
1 Tarigan, H.G. (1986). Pengajaran Semantik. Bandung: Angkasa. P. 11

2 Tarigan, H.G. (1986). Pengajaran Semantik. Bandung: Angkasa. P. 1
} 


\section{Reflinda}

ideas or information provided by the author. Either explicitly or implicitly, in order to understand this activity the reader actively uses his knowledge, experience, and abilities to capture the message correctly and correctly.

By reading a person forms the facts behind the symbol or symbol of the written language. Reading is not merely seeing and interpreting the explicit, but must also be able to see and discover and interpret what is implied behind the written symbols.

Intensive reading essentially requires a short reading material. In intensive reading, required a deep and detailed understanding of a reading material. This level of understanding is closely related to the speed of reading. Reading speed will decrease if depth and comprehension comprehension increase or increase. Another factor that can affect the speed of reading is the clarity of text reading. Clear reading material is certainly easier to understand than the less obvious reading material ${ }^{3}$.

With the above descriptions, it can be concluded that reading comprehension is an active mental process in transforming the visual forms of a language (graphics, words, morphemics, and syntactic into a system of meanings (semantics), in order to form understanding and use (apply) that understanding in the follow-up.

\section{Interest of Reading}

Buchori ${ }^{4}$ states that in all interests there are two aspects that always exist, namely the aspects of cognitive and affective aspects. The cognitive aspect of interest is based on developed concepts of interest-related fields, gained from personal experience and learned at home, at school, and in society, as well as from various types of mass media. Everything you want to know about yourself and others can be satisfied by asking questions and by reading.

From some of the expert opinions above, it can be said that interest is a manifestation of the tendency of the soul, in the form of passion or desire, which can encourage someone to be interested and feel happy about something or a particular activity. So, interest is a tendency of the soul that helps the realization of an action or behavior, expression or statement, and a person's reaction or participation to something or a particular activity that can arouse pleasure.

\footnotetext{
3 Tarigan, H.G. (1986). Pengajaran Semantik. Bandung: Angkasa. P. 41

4 Buchori, M. (1985). Psikologi Pendidikan. Jakarta: Aksara Baru. P. 136
} 
The Effect of Learning Strategy and Reading Interest to the Reading Understanding Ability of Students of IAIN Bukit Tinggi

Interest in reading is a tendency of the soul that can make a person become happy and interested in reading material that he chooses. Sjamsir explained that students who are interested in reading will seem to continue to feel compelled to study diligently. This is certainly different from students who have no interest in learning, his attitude only received lessons and difficult to be persevering because there is no pusher.

To foster and develop student's interest in reading can not be separated from the students' reading ability, because being a person who likes to read must be able to read. Without having the ability to read it may not feel happy in reading. Therefore, the interest to read must be absolutely grown among students in particular and among the public in general, both in the present and in the future.

\section{a. Discovery Learning StrategyStrategi Pembelajaran Diskoveri}

Sanjaya ${ }^{5}$ declare a learning strategy Diskoveri or inkuiri is a student-centered strategy in which groups of learners conduct an investigation and research into an issue or seek answers to the content of questions through a clearly defined and structurally outlined procedure.

Jacobsen, Eggen dan Kauchak ${ }^{6}$ explains that the main characteristics of Discoveri learning strategy are: (1) Discoveri learning strategy emphasizes maximal learners' activity to search and find, meaning learning strategy Discoverion puts the students as subject of learning, (2) all activities undertaken by learners directed to seek and find the answers themselves of the questionable things, so hopefully to grow selfconfidence, and (3) the purpose of using learning strategies Diskoveri is to develop the ability to think systematically, logically and critically or develop intellectual ability as part of the mental process.

Further explained Jacobsen, Eggen and Kauchak explain the importance of applying Discoveri learning are: (1) through learning Discoversi, teachers can teach investigative and systematic skills to learners, (2) through learning Discoversi provides

5 Wina Sanjaya. (2007). Strategi Pembelajaran Berorientasi Standar Proses Pendidikan. Jakarta: Kencana Prenada Media Group.

${ }^{6}$ Jacobsen, D.A., Eggen, P dan Kauchak, D. (2009). Methods for Teaching, Metode-Metode Pengajaran Untuk Meningkatkan Belajar Siswa TK-SMA Translator: Ahmad Fawaid dan Khoirul Anam. Yogyakarta: Pustaka Pelajar 


\section{Reflinda}

experience to learners to apply their knowledge to aspects other life aspects, and (3) through learning Discovers students are actively involved in each stage of learning.

Suyanti explained that Discoveri learning strategy is supported by four main characteristics of learners: (1) intuitively learners always want to know, (2) in conversation learners always want to talk and communicate their idea, (3) in building participant students always want to make something, and (4) learners want to express their abilities. Furthermore, Suyanti explain the principles contained in the implementation of learning strategy Diskoveri namely: (1) oriented to intellectual development, in this case the development of thinking skills and learning-oriented, (2) the principle of interaction, in this case the learning process is the interaction between learners with educators, (3) the principle of asking, in this case the teacher acts as a questioner because the ability of learners to ask is basically already part of the thinking process, (4) the principle of learning to think, in this case the process of developing the potential of the whole brain to the maximum, and (5) the principle of openness, in this case the students are given the freedom to try something in accordance with the development of logic ability and reason.7

Syntax of learning Discovery presented Jacobsen, Eggen and Kauchak, Trianto are: (1) identifying problems, (2) forming hypotheses, (3) collecting data, (4) analyzing data and making conclusions. It is further explained that the direct learning impact of the Discoveri learning strategy is to develop process skills and improve the ability to perform activities creatively. Then as a companion effect of discovery learning strategy is to increase the spirit of student creativity, freedom in learning, respect the opinions of others.

\section{b. Expository Learning Strategy}

Sanjaya ${ }^{8}$ explains expository learning from the view that student behavior and knowledge distribution are controlled and determined by the teacher. Therefore the essence of teaching according to this view is to convey science to students who are placed as objects that receive what is given by the teacher. Usually teachers convey information about learning materials in the form of explanations and oral narratives,

7 Suyanti, R.D. (2008). Strategi Pembelajaran Kimia. Medan: Pasca Unimed

8 Wina Sanjaya. (2007). Strategi Pembelajaran Berorientasi Standar Proses Pendidikan. Jakarta: Kencana Prenada Media Group. P. 177 
The Effect of Learning Strategy and Reading Interest to the Reading Understanding Ability of Students of IAIN Bukit Tinggi

namely by lecture method. Expository learning requires students to capture and remember the information the teacher has given, and to re-reveal what he has mimicked into the response he gave when the teacher asked questions. Here there is a one-way communication, because it is less optimal student learning process because it is limited to listening to record what the teacher submitted.

In an expository learning strategy students are treated as objects or clients, teachers function as the highest authority and scholarly doctrinator, subject matter is subject oriented. This is in line with Majid's opinion, Zamroni ${ }^{9}$ which explains that the expository strategy is more input-oriented, ie what material should be conveyed to the students as the curriculum demand or the target of curriculum target achievement, this undemocratic climate causes the learning process to be static and frozen and cause a destructive effect on curiosity, confidence, creativity, and freedom among learners.

The assumptions underlying the application of an expository learning strategy as described by $\mathrm{Lie}^{10}$ can be categorized into four, namely; (1) the learning process is an effort to transfer the knowledge of the teacher to the student (the task of a teacher is to receive, the teacher, provide information and expect the students to memorize and remember it), (2) the students are considered empty bottles that are ready filled with knowledge (the student is the recipient of passive knowledge, teachers have knowledge that will be memorized by the students), (3) mengkotak-kotakkan students (teachers classify students based on the value and student input in categories, homogeneous grouping, who is worth following the seed and who is not worth), (4) students in the competition (students work hard to beat their classmates, who is strong, he who wins, parents compete each other boasting each child and highlight the achievement of his son as a showcase of chicken complaint).

\section{METHODOLOGY}

This research was conducted at IAIN Bukittinggi in PAI Department. The study was conducted for 4 months from August to November 2015 including the implementation of the test. Determination of treatment schedule adjusted to lecture

${ }^{9}$ Zamroni. (2000). Paradigma Pendidikan Masa Depan. Yokyakarta: Bigraf Publissing. Hlm

10 Anita Lie (2004). Cooperative Learning, Mempraktikkan Cooperative Learning di RuangRuang Kelas. Jakarta: Grasindo Maksan. P. 3 


\section{Reflinda}

schedule. The population in this study is all students of Semester 5 at the Department of Religious Education at IAIN Bukittinggi. Characteristics of students scattered in the four classes are not grouped into rankings and classification of superior classes but the student distribution is done randomly only when the placement of students in their respective class groups. The sampling technique used cluster random sampling. Samples taken consisted of two groups namely, one group of classes conducted learning using learning discoveri and one other class conducted expository learning. Researchers themselves become Teachers in each class.

The research design that will be used is $2 \times 2$ factorial design as shown in Table 1 below: ,

Table 1 Research Design

\begin{tabular}{|c|c|c|}
\hline Learning Strategy & $\begin{array}{c}\text { Discovery } \\
\left(\mathrm{A}_{1}\right)\end{array}$ & $\begin{array}{c}\text { Expository } \\
\left(\mathrm{A}_{2}\right)\end{array}$ \\
\hline Interest of Learning & $\mathrm{A}_{1} \mathrm{~B}_{1}$ & $\mathrm{~A}_{2} \mathrm{~B}_{1}$ \\
\hline High $\left(\mathrm{B}_{1}\right)$ & $\mathrm{A}_{1} \mathrm{~B}_{2}$ & $\mathrm{~A}_{2} \mathrm{~B}_{2}$ \\
\hline
\end{tabular}

In accordance with the research problems formulated, the techniques used in analyzing the data to see the differences in teaching and learning strategies influence the reading interest of students to the learning outcomes of reading comprehension is $t$ test analysis (different test) between each group.

\section{FUNDINGS}

\section{A. Description of Fundings}

\section{The Result of Understanding Reading of Students taught by using Discovery}

\section{Learing Strategy.}

Data on learning outcomes Understanding Reading students who were taught by learning strategies Diskovesri obtained price mean $(1)=73.75$; mode $=70$; median $=70$; variance $=110,42 ;$ standard deviation $=10.51$; highest score $=95 ;$ and the lowest score $=$ 60. Based on the distribution of this data indicates that the mean, median and mode values tend to have the same distribution and the difference in numbers is no more than one standard deviation indicating that the data distribution tends to be normally distributed. 
The Effect of Learning Strategy and Reading Interest to the Reading Understanding Ability of Students of IAIN Bukit Tinggi

\section{The Result of Understanding Reading of Students taught by using Expository}

\section{Learing Strategy.}

Data on learning outcomes Understanding Reading students who were taught with Expository learning strategy obtained the mean price $(2)=61.6$; mode $=60$; median $=60$; variance $=45.25 ;$ standard deviation $=6.73$; highest score $=70$; and the lowest score $=55$. Based on the distribution of this data shows that the mean, median and mode have relatively similar numbers, this indicates that the data distribution tends to be normal distribution.

\section{B. Hypothesis Testing}

\section{First Hypothesis}

Hypothesis testing is done by using Independent Sample $\mathrm{T}$ test to test the first hypothesis. Based on the results of the analysis conducted by using SPSS Program in the following results:

Table 2 Descriptive Statistics Understanding Class Reading Discovers with Expository Classes.

\begin{tabular}{|l|l|r|r|r|r|}
\hline \multicolumn{2}{|l|}{ Class } & N & Mean & $\begin{array}{c}\text { Std. } \\
\text { Deviation }\end{array}$ & $\begin{array}{c}\text { Std. Error } \\
\text { Mean }\end{array}$ \\
\hline & Discovery & 28 & 73.75 & 10.51 & 1.986 \\
\cline { 2 - 6 } & Expository & 25 & 61.60 & 6.73 & 1.345 \\
\hline
\end{tabular}

Based on the data above shows that the average Learning Outcomes Understanding Reading class Discovers with Expository class are 73.75 and 61.60 with standard deviation of 10.51 and 6.73 .

The results of hypothesis testing using t-test that serves to test whether the average value between these two groups differ significantly is presented in Table 3 below.

Table 3.

Summary The results of Beda (t-test) test analysis between Discoveri class and Expository class.

\begin{tabular}{|c|c|r|r|r|r|r|}
\hline \multicolumn{2}{|c|}{$\begin{array}{c}\text { Levene's } \\
\text { Test for } \\
\text { Equality of } \\
\text { Variances }\end{array}$} & \multicolumn{5}{|c|}{ t-test for Equality of Means } \\
\hline F & Sig. & $\mathrm{t}$ & $\mathrm{df}$ & $\begin{array}{c}\text { Sig. (2- } \\
\text { tailed) }\end{array}$ & $\begin{array}{c}\text { Mean } \\
\text { Differenc } \\
\mathrm{e}\end{array}$ & $\begin{array}{c}\text { Std. Error } \\
\text { Difference }\end{array}$ \\
\hline 8,328 & 0,006 & $\mathbf{4 , 9 4 4}$ & $\mathbf{5 1}$ & $\mathbf{0 , 0 0 0}$ & $\mathbf{1 2 , 1 5}$ & $\mathbf{2 , 4 6}$ \\
\cline { 2 - 7 } & 5,065 & 46,46 & 0,000 & 12,15 & 2,40 \\
\hline
\end{tabular}


Based on Table 3 above we can see that the price $F=8.328$ with Sig. $=0.006$, this indicates that the data of both groups are not homogeneous. Because the data is not homogeneous then to see the next analysis used data on the second line. Based on test above seen that $\mathrm{t}$ value $=5,065$ with sig value. $=0.00<0.05$. This shows that the average difference between the two groups is significantly different (real). Based on the results of this analysis can be concluded that Ho is rejected and $\mathrm{H} 1$ accepted.

The results of this analysis prove that "Students who are taught with discovered learning strategies with guidance in learning obtain higher learning outcomes than on learning done with expository learning strategies".

\section{Second Hypothesis}

To test the second hypothesis used $\mathrm{t}$ test test between discoverion group and expository. The results of descriptive statistical analysis can be seen from Table 4.5 below

Table 4.

Results of reading group reading Disclosure of high reading interest with high interest reading expository.

\begin{tabular}{|l|l|c|c|c|}
\hline $\begin{array}{l}\text { Highest Reading } \\
\text { Interest }\end{array}$ & Group & $\mathrm{N}$ & Mean & $\begin{array}{c}\text { Std. } \\
\text { Deviation }\end{array}$ \\
\hline $\begin{array}{l}\text { Reading } \\
\text { Understanding }\end{array}$ & Discovery & 12 & 73,333 & 9,129 \\
\cline { 2 - 5 } & Expository & 10 & 61,00 & 6,583 \\
\hline
\end{tabular}

The table above shows the mean and standard deviation values of the two groups. From this table it can be seen that the average score of reading comprehension of Discovered students with high reading interest is 73.33 with standard deviation of 9 , 129 , while for expository class $=61,00$ with standard deviation $=6,583$. To see if there is any difference between these two groups can be significantly seen in the following $t$ test table.

Tabel 5.

Test Results Different Class Discovers with Expository class with High Read Interest 
The Effect of Learning Strategy and Reading Interest to the Reading Understanding Ability of Students of IAIN Bukit Tinggi

\begin{tabular}{|c|c|r|r|r|r|r|}
\hline \multicolumn{2}{|c|}{$\begin{array}{c}\text { Levene's } \\
\text { Test for } \\
\text { Equality of } \\
\text { Variances }\end{array}$} & \multicolumn{5}{|c|}{$\mathrm{t}$-test for Equality of Means } \\
\hline F Sig. & $\mathrm{t}$ & $\mathrm{df}$ & $\begin{array}{r}\text { Sig. (2- } \\
\text { tailed) }\end{array}$ & $\begin{array}{c}\text { Mean } \\
\text { Difference }\end{array}$ & $\begin{array}{c}\text { Std. Error } \\
\text { Differenc } \\
\mathrm{e}\end{array}$ \\
\hline \multirow{2}{*}{1,786} & 0,196 & 3,673 & $\begin{array}{r}19,65 \\
7\end{array}$ & 0,002 & 12,33 & 3,358 \\
\cline { 3 - 7 }
\end{tabular}

The table above shows that the distribution of discoveri group data and homogeneous Expository group with value $\mathrm{F}=1.786$ and Sig value. $=0.196>$ alpha 0.05. Based on test also seen that $t$ test value equal to 3,564 with sig value. $0.002<$ alpha 0.05. The results of this calculation indicate that there is a significant difference between the results of reading comprehension between these two groups.

Based on the above analysis it can be concluded that ho rejected and ha accepted. This indicates that there is a significant difference between high reading interest of the Discoveri group and the high reading interest of the Expository group in which the Diskoveri group has a higher mean value compared to the Expository group.

The results of this analysis prove that "Students who are taught with discovered learning strategies that have high reading interest obtain higher learning outcomes than the learning done with expository learning strategies with high reading interest"

\section{Third Hypothesis}

To test the third hypothesis used $t$ test between discoverion group and expository. The results of descriptive statistical analysis can be seen from Table 4.7 below.

Table 6.

Results of reading group reading Disclosure of low reading interest with Low interest reading Expositories

\begin{tabular}{|l|l|l|l|c|}
\hline $\begin{array}{l}\text { Low Reading } \\
\text { Interest }\end{array}$ & Group & $\mathrm{N}$ & Mean & $\begin{array}{l}\text { Std. } \\
\text { Deviation }\end{array}$ \\
\hline $\begin{array}{l}\text { Understanding } \\
\text { Reading }\end{array}$ & Discovery & 12 & 70,42 & 9,876 \\
\cline { 2 - 5 } & Expository & 10 & 60,00 & 7,071 \\
\hline
\end{tabular}

The table above shows the mean and standard deviation values of the two groups. From this table it can be seen that the average score of reading comprehension 


\section{Reflinda}

of Discovered group students with low reading interest is 70,42 with standard deviation of 9.876, while for Expository class of low reading interest reading comprehension is average $=6,00$ with standard deviation is $=7.071$. Furthermore, to see if there is any difference between these two groups can be significantly seen in the following test $\mathrm{t}$ test table.

Table 7.

Test Results Different Class Discovers with Expository class with Low Read Interest.

\begin{tabular}{|c|c|c|c|c|c|c|}
\hline $\begin{array}{c}\text { Levene's } \\
\begin{array}{c}\text { Test for } \\
\text { Equality } \\
\text { of } \\
\text { Variances }\end{array}\end{array}$ & \multicolumn{6}{|c|}{ t-test for Equality of Means } \\
\hline F & Sig. & T & Df & $\begin{array}{c}\text { Sig. } \\
(2-\text {-tailed })\end{array}$ & $\begin{array}{c}\text { Mean } \\
\text { Difference }\end{array}$ & $\begin{array}{c}\text { Std. Error } \\
\text { Difference }\end{array}$ \\
\hline 2,061 & 0,167 & $\mathbf{2 , 7 8 8}$ & $\mathbf{2 0}$ & $\mathbf{0 , 0 0 1}$ & $\mathbf{1 0 , 4 1 7}$ & 3,736 \\
\cline { 3 - 7 } & 2,875 & 19,621 & 0,009 & 10,417 & 3,623 \\
\hline
\end{tabular}

The table above shows that the distribution of discoveri group data and homogeneous Expository group with value F 2.061 and Sig value. $=0.167>$ alpha 0.05. Based on test also seen that $\mathrm{t}$ test value equal to 2,788 with sig value. $0.001<$ alpha 0.05 . The results of this calculation indicate that there is a significant difference between the results of reading comprehension between these two groups.

Based on the above analysis it can be concluded that ho rejected and ha accepted. This shows that there is a significant difference between low reading interest of Discoveri group with low interest of Expository group where Diskoveri group has higher mean value compared to Expository group.

The results of this analysis prove that "Students who are taught with disclosure learning strategies that have low reading interest earn higher reading comprehension than learning done with expository learning strategies with low reading interest".

\section{DISCUSSION}

Based on the results of research that has been done has been proven that learning by using the learning strategy Diskoveri provide learning results reading comprehension better than the expository learning strategy. This is in line with the theory that has been discussed in Chapter II that in terms of learning process Discoveri strategy provides an opportunity for students to make learning process better in terms 
The Effect of Learning Strategy and Reading Interest to the Reading Understanding Ability of Students of IAIN Bukit Tinggi

of cognitive and activities undertaken in the learning process so it is not surprising that this staregi give good impact to students.

The effectiveness of learning strategies class in achieving learning objectives can be seen from how high the achievement of student achievement. Dick, Carey and Carey explained that learning strategies describe the common components of a set of learning materials used to produce student learning. In the learning strategy contained four components, namely: (1) sequence of learning activities, namely the sequence of teaching activities in conveying the content of the lesson to the students, (2) instructional learning strategy, the way teachers organize learning materials and students in order to occur the process of learning effectively and (3) instructional media, ie tools and learning materials used by teachers and students in the learning process, and (4) time spent by the students and students in completing each step in the learning activities. To know the level of effectiveness of the learning strategy yag diguanakan in the learning process for a certain time, then the size is the result of student learning

If this strategy combined with interest in reading both high reading interest and low interest reading, the results are also still quite good. This provides clear information that although students have a low reading interest when taught learning strategies Discussion results reading students' understanding is still better when compared with expository learning strategies. The explanation of why a better discovery learning strategy can be read from Sanjaya's opinion below.

Sanjaya ${ }^{11}$ explains that the main characteristics of discover learning strategy are: (1) Discoveri learning strategy emphasizes maximal learners' activity to search and find, meaning learning strategy Discoverion puts students as subject of learning, (2) all activities undertaken by learners directed to search and find the answers themselves of the questionable things, so hopefully to grow self-confidence, and (3) the purpose of using learning strategies Diskoveri is to develop the ability to think systematically, logically and critically or develop the intellectual ability as part of the mental process.

\section{CONCLUSION}

11 Wina Sanjaya. (2007). Strategi Pembelajaran Berorientasi Standar Proses Pendidikan. Jakarta: Kencana Prenada Media Group. 


\section{Reflinda}

Based on the results of research that has been done the researchers then put forward some conclusions as follows:

1. 1. Understanding of reading students who are taught with learning strategies Discovers with guidance is significantly higher than in students who are taught with Expository learning strategy. With an average difference of 73.75 for Discoveri learning and 61.6 for Expository learning, whereas t count $=4.944$ and sig. $=0.00$.

2. 2. Understanding of reading students with high reading interest of the class Discovers understanding of reading significantly higher than in students with high interest in reading Expository class. The average value of the Discovery class $=73.33$ and the Expositor class is 61.00 with $\mathrm{t}=3.564$ and sig. 0.002 .

3. 3. Understanding of reading students with low reading interest Class Diskover understanding of reading is higher than the students with low reading interest Expository Class. The average value of class Discoveri $=$ 70,42 and Expositor class 60,00 with $\mathrm{t}$ count $=2,788$ and sig. 0.001 .

\section{BIBILIOGRAPHY}

Buchori, M. (1985). Psikologi Pendidikan. Jakarta: Aksara Baru.

Dick, W. dan Carey, L. (1996). The Systematic Design of Instruction. Fouth Edition. New York: Harper Collin College Publisher

Jacobsen, D.A., Eggen, P dan Kauchak, D. (2009). Methods for Teaching, Metode-Metode Pengajaran Untuk Meningkatkan Belajar Siswa TK-SMA Penerjemah: Ahmad Fawaid dan Khoirul Anam. Yogyakarta: Pustaka Pelajar

Joyce, B. Weil, M.dan Calhoun, E. (2009). Models of Teaching, Model-Model Pengajaran. Penerjemah: Achmad Fawaid dan Ateila Mirza, Yogyakarta: Pustaka Pelajar.

Lie, A. (2004). Cooperative Learning, Mempraktikkan Cooperative Learning di Ruang-Ruang Kelas. Jakarta: Grasindo Maksan.

Rohani, A. dan Ahmadi, A. (1995). Pengelolaan Pengajaran. Jakarta: Rineka Cipta

Romizowski, AZ. (1981). Designing Instructional System. New York: Nichol Publishing Company 
The Effect of Learning Strategy and Reading Interest to the Reading Understanding Ability of Students of IAIN Bukit Tinggi

Sanjaya, W. (2007). Strategi Pembelajaran Berorientasi Standar Proses Pendidikan. Jakarta: Kencana Prenada Media Group.

Sjamsir, Alim. (1996). Perpustakaan Sekolah Sebagai Sarana Pengembangan Minat dan Kegemaran Membaca. Jakarta: Depdikbud.

Suyanti, R.D. (2008). Strategi Pembelajaran Kimia. Medan: Pasca Unimed

Tarigan, H.G. (1986). Pengajaran Semantik. Bandung: Angkasa.

Trianto, (2009). Mendesain Model Pembelajaran Inovatif Progesif. Jakarta: Kencana Prenada Media Group

Zamroni. (2000). Paradigma Pendidikan Masa Depan. Yokyakarta: Bigraf Publissing. 